\title{
近赤外分光法を用いた 見まねによる動作学習時における脳賦活反応計測
}

\section{Measurement of brain activity related to behavior acquisition by imitation learning using near-infrared spectroscopy}

\author{
Yusuke ASAKA ${ }^{* 1}$ \\ ${ }^{* 1}$ Guraduate School of Science and Engineering, Saitama Universicy \\ 255 Shimo-okubo, Sakura-ku, Saitama-shi, Saitama 338-8570, Japan
}

Received: 8 November 2020; Revised: 21 January 2021; Accepted: 15 February 2021

\begin{abstract}
According to David Marr, three levels are needed to understand information processing systems. Those are "computational theory", "representation" and "algorithm and hardware implementation". This idea improves understanding brain function and technological application in a mutually complementary manner. On the other hand, the development of measuring brain function enabled us to apply brain activities to engineering. Measuring brain activity have been used for the evaluation method to information that is difficult to quantify such as emotion and learning levels. This work investigates the relationships between learning levels and brain activities. In the conducted experiment, subjects firstly learned a set of procedures for assembling work by observation and then imitated the procedures in the tasks. After several practices, they participated in the same tasks. The results indicates that activities of regions of dorsolateral prefrontal cortex (DLPFC) have increased at pre-learning and a wide region of prefrontal area have increased at post-learning during the observation. In the imitation, regions of DLPFC were activated at pre-learning. At the post-learning, the regions of DLPFC, frontopolar cortex and inferior prefrontal gyrus were activated. These findings are accorded with the results of the previous studies and suggest the necessity of considering the effects of a default mode network on the brain activities of imitation learning.
\end{abstract}

Keywords : Skills, Brain activity, Near-infrared spectroscopy, Imitation learning, Knowledge acquisition

\section{1. 緒言}

近年，人工知能の性能が飛躍的に向上し，多様な課題がコンピュータにより実行可能となった．内閣府は 2016 年から第 5 期科学技術基本計画として, Society5.0 を提唱している（内閣府, 2020). 科学技術が先導し，サイバ 一空間とフィジカル空間（現実社会）が高度に融合した，情報社会に続く新たな社会を生み出すことを取組の目 標としている．機械が人間社会に深くかかわり，人の生活空間で機能することは，社会的に求められており，こ れからもその需要は増加すると考えられている (富士経済, 2020; 今井他, 2020; 尾崎, 2020). ヒトの生活圈におい てロボットが社会的に浸透し，機能するためには，ヒトとの円滑なコミュニケーションや，変化する多様な人間 の生活空間に，継続的に適応し続ける能力を有することが望ましい，その適応を学ぶ手法として，見ま㸚学習が 有効な手段のひとつであると考えられる.

他者の振舞いを介して学ぶという行為は, 有用な学習手法のひとつであり, 学術的にも広く興味の対象となっ ている. 観察学習や模倣学習は心理学において研究の対象となっており，生後 9 か月の乳児においても遅延模倣 の能力が存在し，子供の社会的な発達に重要な役割を果たしている可能性が示されている (Meltzoff, 1988). 1992 年にはミラーニューロンが発見され (Pellegrino et al., 1992), ヒトにおいてもその存在が示唆されており（Fadiga et al., 1995), 他者を真似るという行為の重要性が明らかになった。ロボット工学においては, ロボットの学習手法

No.20-00405 [DOI:10.1299/transjsme.20-00405], J-STAGE Advance Publication date : 25 February, 2021

${ }^{* 1}$ 正員, 埼玉大学大学院 理工学研究科（†338-8570 埼玉県さいたま市桜区下大久保 255)

E-mail of corresponding author: y.asaka.962@ms.saitama-u.ac.jp 
として，見ま䄈学習の研究が行われている（田㴊他, 2006）。先行研究においては, ヒトの脳機能や学習理論を背 景とした研究アプローチも行われており（鮫島他, 2001; 稲邑, 中村, 2005; 清水, 久保田, 2006), ロボットの学習 手法としてだけでなく, ヒトの見ま礽学習についても知見を与えている. 神経科学の研究者である Marr は, 情報 処理を実行する機械を理解するのに必要な三つの水準として, 計算理論, 表現とアルゴリズム, ハードウェアに よる実現を挙げており（Marr 他, 1987), 見まね学習におけるヒトの情報処理システムの理解とロボット工学にお ける学習の発達は, 相互補完的に発展可能であると考えられる.

また感性工学の分野においては, ヒトの脳賦活反応を計測することで, 感性や習熟といった数值化が困難である 情報を評価するといった試みがなされてきた（鳥山他, 2020; 相原他, 2019). 脳機能計測技術が発達したことで, 脳賦活反応を生理的な指標として，工学的な応用が可能となりつつある.

本研究では, 見ま祗学習の習熟度を脳賦活反応に基づいて評価することを目的として, 近赤外分光法（NIRS: Near-infrared spectroscopy）を用いた動作獲得前後における皮質活動の解析を行う。筆者らは，これまでに身体知 の獲得程度を脳賦活反応に基づいて評価することを目的として, 製造業における作業の見まね学習による習熟と 脳賦活反応の関係について, 実験を行った（淺賀, 綿貫, 2016)。大域平均基準 （野澤, 近藤, 2009）を用いて, 右 外側前頭前野と左外側前頭前野，前頭極に着目して解析を行い，局所的な脳賦活反応の傾向について述べた。一 方, Tak らによって開発された統計解析ソフトである NIRS-SPM は, 広く用いられ, 多くの知見を与えている（Ye et al., 2009; Jang et al., 2009; Tak et al., 2010; Tak et al., 2011; Li et al., 2012). 本論文では, この NIRS-SPM を用いて, 作業習熟前後の脳賦活反応について, 解析を行う. そして, これまでの局所的な脳賦活反応傾向の考察に加えて, 計測部位全体の脳賦活反応傾向について, 作業習熟との関連性を考察する.

\section{2. 実験}

\section{$2 \cdot 1$ 目的}

本研究は, 見ま衫による動作獲得程度を, 脳賦活反応に基づいて評価することを目的としている. 先行研究で は，追跡回転課題（Pursuit Rotor Task）を用いて，運動技能の習得に伴い前頭前野の活性が変化することが示され ている（Hatakenaka et al., 2007）。また，内視鏡手術の技能獲得に関しても，被験者である外科研修医の前頭皮質 が活発化し，内視鏡手術の訓練後においては，それまで経験のない初心者も前頭皮質において活発化する等，活 性が変化することが示された（Ohuchida et al., 2009). 当実験では，学習方法を見まねとして，学習時及び作業時 双方の脳機能計測を行う。また，NIRS は低拘束性であり，被験者への負担も少ないため，継続的な実験が比較

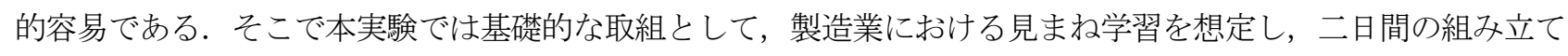
作業を行う。見ま氷習による作業習得前後の脳活動を計測し, 計測部全体の脳賦活反応傾向と作業習熟との関 連性を考察する。

\section{$2 \cdot 2$ 近赤外分光法による脳機能計測}

NIRS による脳機能計測では, 生体内を透過しやすい 700 900nm の近赤外光を被験者の頭皮上から照射し, 内 部を通過して散乱してきた近赤外光を計測することで，対象部分の酸素化へモグロビン（Oxy-Hb）と脱酸素化へ モグロビン（Deoxy-Hb）の変化量を導出する．計測原理は，基礎的には Lambert-Beer の法則に基づく．NIRS は 計測チャンネル数が単一のものと複数のものとに大別でき, 複数チャンネルの計測システムは, 頭部の断層像を 得る拡散光イメージング（DOT: Diffusion Optical Tomography）と, 脳表面のトポグラフィックな画像を得る光卜 ポグラフィとに分類される（江田, 2009）.

NIRS は他の脳機能計測機に比べて, 可搬性に優れており, 時間分解能が高く, 被験者への負担も少ない. 稼 働中の騒音も少なく，乳幼児を対象とした脳機能研究においても使用される.

\section{$2 \cdot 3$ 実験方法}

被験者は机の前の椅子に座り, 机よりも前方に設置されたディスプレイを見つめる. 実験は 3 試行で 1 組とす る. 1 試行は 30 秒間の安静状態を保ち，実験課題を 180 秒間行い，再び 30 秒間の安静状態を保つ，という構造 である. 1 試行目の実験課題では, 安静状態を保つ課題（安静課題）であり, 被験者は 1 試行目の全体を通して 
安静状態を保つ. この安静課題は, 他の課題における脳賦活反応と比較する目的で設定する. 2 試行目はディス プレイに表示された作業の見本となる映像を観察する課題（観察課題）である. 課題開始後の 5 秒間は，被験者 に指示をする映像を呈示し, 課題終了前の 5 秒間は, 課題終了を伝える映像を 5 秒間呈示する. 3 試行目では, 実験開始前に，机の上に 2 試行目の映像で提示した組み立て作業の部品を設置する. 課題開始後の 5 秒は, 2 試 行目と同様に被験者への指示が映像で呈示される．被験者は 2 試行目で観察した作業と同じ作業を見本と同様の 手順に則り，再現をする課題（再現課題）を行う。課題終了 5 秒前には，被験者に終了を伝える映像を呈示する と同時に，ブザーによって合図を行う．実験前には被験者に実験構成の説明と，実験中に見本として呈示される 映像により，作業手順を覚えるように指示をする．実験の構成を図 1 に示す．また，図 2 に実験で行う組立作業 を示す．被験者は無作為に配置された部品を組み立て，ひとつの完成品とする．本実験では，相手の意図やアフ オーダンスを理解することではなく, 作業の過程を真似ることを重視し, 完成品は左右非対称であり, 形や機構 に特別な意味を持たないようなものを選定した.

実験 1 日目の終了後, 被験者は 2 試行目の課題と，3 試行目の課題を再度行う. 2 日目の実験前には, 2 試行目 の課題と 3 試行目の課題を 2 回連続で行い, その後に実験を行う. 表 1 に, 練習を含めた被験者の行う課題の全 体を示す.
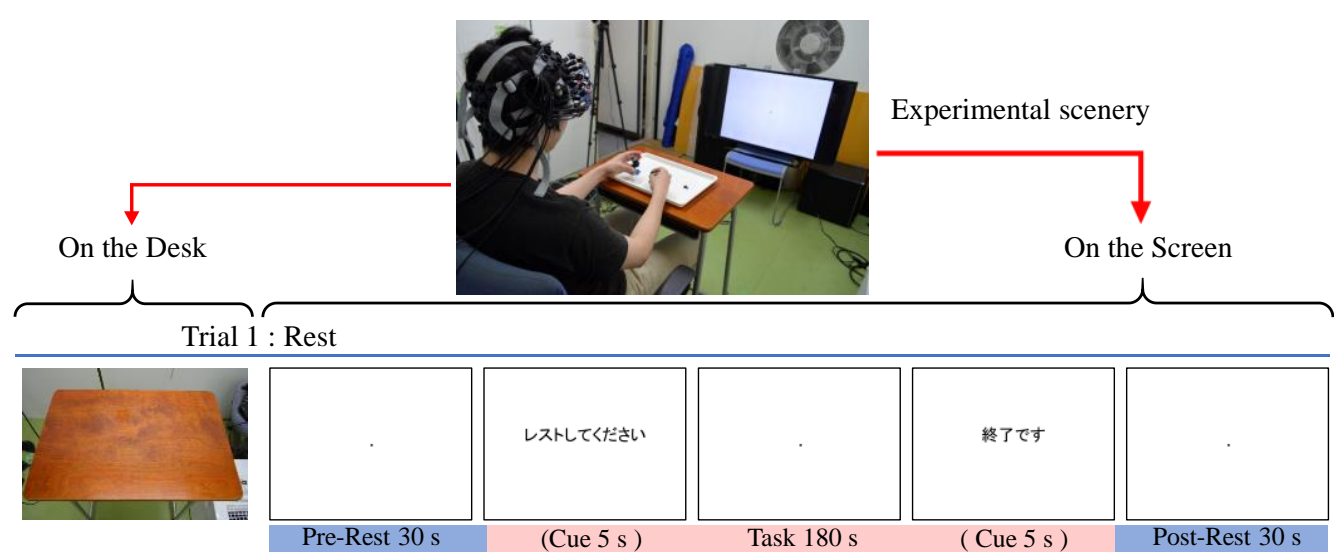

Trial 2 : Observation
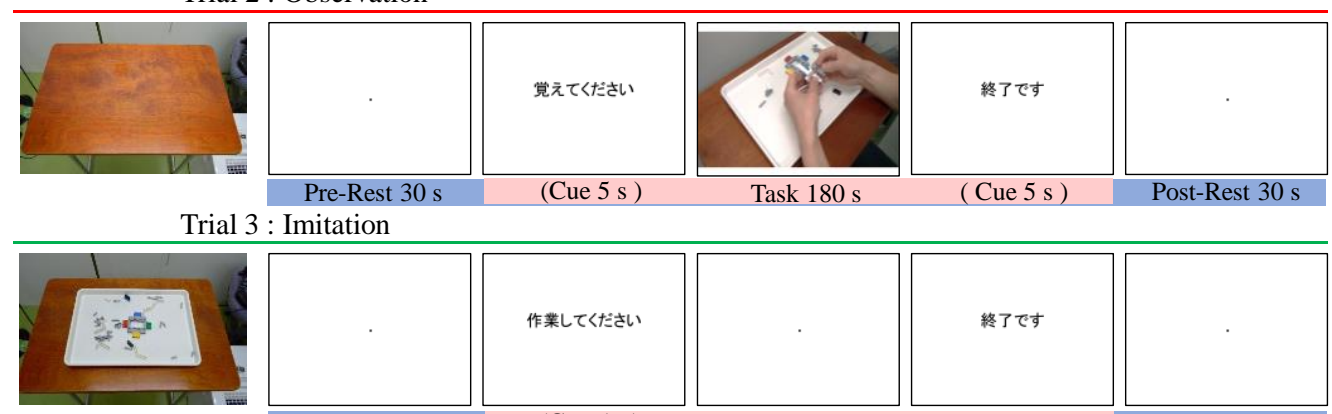

Imitation

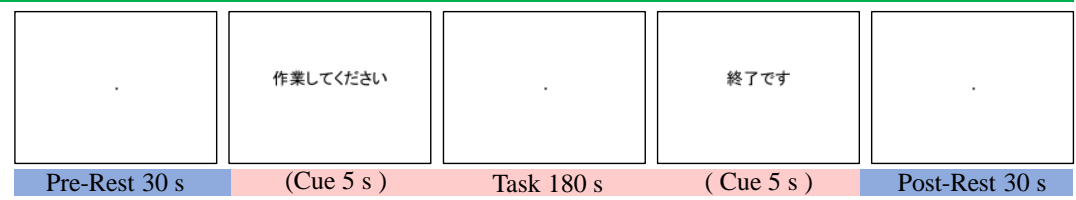

Fig. 1 Experimental design. An experiment has three trials which contain rest task, observation task and imitation task. Subjects continue to rest in rest task and observe a set of procedures in observation task. During imitation task, they imitate procedures following the observed model.
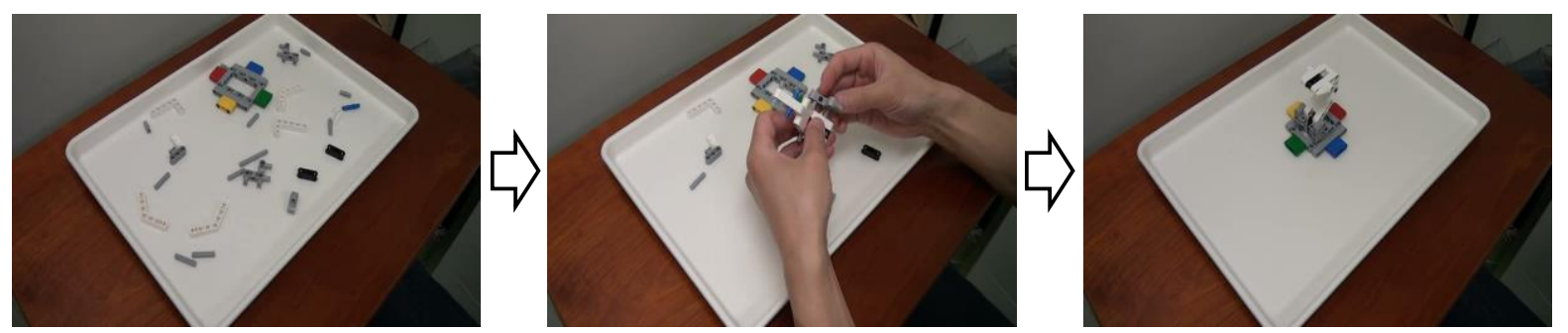

Fig. 2 Assembling work of the experiment. Subjects assemble parts which are placed at random following an order of the observed model. 


\section{$2 \cdot 4$ 被験者及び計測部位}

被験者は 20 代の男性 5 名（被験者 $\mathrm{A}, \mathrm{B}, \mathrm{C}, \mathrm{D}, \mathrm{E}$ であり，平均年齢 $22.2 \pm 1.2$ 歳）である. 全員右利きであ り，実験当日は健康状態に問題のないことを事前に確認した．実験は 2 日間行う。見まね学習による作業習得前 に計測を行い，後日，作業内容の習得後に再び計測を行う。サルを用いた実験では背外側前頭前野でワーキング メモリー機能との関与が示されている（甘利, 田中, 2008)。 また, 被験者が後に思い出せた単語を学んでいると きには, 左下前頭前皮質の一部において脳活動が高まったことが示唆されている (Wagner et al., 1998). そのため, 脳賦活反応の計測部位は前頭前野とした．図 3 のように測定位置のチャンネル（Ch.）は，国際 10-20 法に基づい て Fpz：前頭極に対応するように設置する.

なお本実験においては，実験前に被験者に対して実験の内容と目的を説明し，実験参加への同意を得てい る.また，実験について，埼玉大学倫理委員会の承認を得て実施した（受付番号 H26-31）。

\section{$2 \cdot 5 \quad$ 組み立て作業の習熟度の評価}

本実験においては，見まねによる作業習得前後の脳活動を計測する．2 回の実験において，被験者は 1 回目の 実験後と 2 回目の実験前に, 同様の作業内容について見ま敉学習を行う。実験時の再現課題における習熟程度の 評価は，加算方式により行う。見本として提示した作業内容について，手順を 12 の工程に分割する. 分割された 工程における作業を満たした場合，その工程を達成したと見なす．被験者の達成した工程が，見本に沿っていれ ば，点数を加算する．作業手順を遡った場合には，分割された工程において正しく作業を行っていても，加点は しないものとする. 評価は 11 点満点となる. 組立作業における部品については, 形状及び色の左右非対称は区別 する. 本実験においては, 再現課題の習熟度がこの点数で示される.

この習熟度によって実験結果を分類し, 習熟度の低い条件の脳賦活反応と, 習熟度の高い条件の脳賦活反応に おいて, 別の傾向が見られるのか解析する. 脳賦活反応において別々の傾向が見られるのであれば，より高度で 複雑な作業習得についても，脳賦活反応によって，習熟度を評価できる可能性が考えられる.

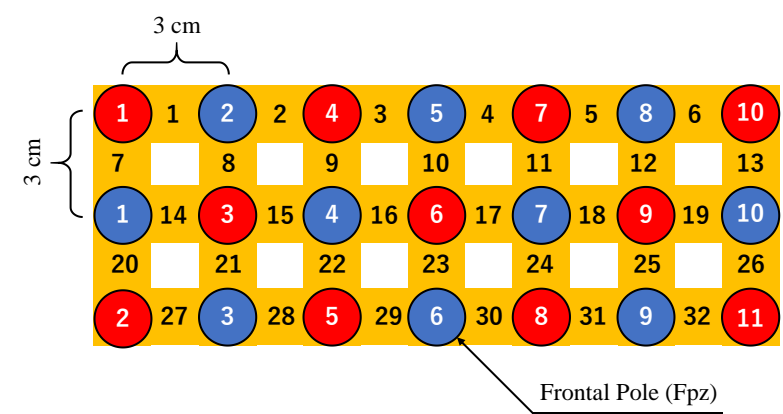

Fig. 3 Optodos positions of the 32 NIRS channels. Red circles are illuminators and blue circles are detectors.

Numbers indicate index of illuminators, detectors and channels. A position of No.6 detectors corresponds to Fpz of International ten-twenty system.

Table 1 Experimental schedule. Numbers indicate the subjects' performance counts.

\begin{tabular}{|c|c|c|c|c|}
\hline \multirow{2}{*}{} & \multicolumn{2}{|c|}{ First day of the experiment } & \multicolumn{2}{c|}{ Second day of the experiment } \\
\cline { 2 - 5 } & $\begin{array}{c}\text { Measurements } \\
\text { by NIRS }\end{array}$ & $\begin{array}{c}\text { Practices after } \\
\text { measurements }\end{array}$ & $\begin{array}{c}\text { Practices before } \\
\text { measurements }\end{array}$ & $\begin{array}{c}\text { Measurements } \\
\text { by NIRS }\end{array}$ \\
\hline $\begin{array}{c}\text { Task 1 } \\
\text { Rest }\end{array}$ & 1 & - & - & 1 \\
\hline $\begin{array}{c}\text { Task 2 } \\
\text { Observation }\end{array}$ & 1 & 1 & 2 & 1 \\
\hline $\begin{array}{c}\text { Task 3 } \\
\text { Imitation }\end{array}$ & 1 & 1 & 2 & 1 \\
\hline
\end{tabular}




\section{3. 評価と考察}

\section{$3 \cdot 1$ 被験者の習熟度の変化}

表 2 に被験者の実験初日と練習後の 2 回目の実験における，見本となる動作手順との比較に基づいた，習熟度 の評価結果を示す．初日の実験においては，0 点から 2 点であったのに対し，練習を経験した 2 回目の実験にお いては，10点という結果になった．初見で観察した作業を模倣した際には再現できなかった作業が，練習後には 作業作業に習熟したことが分かる.

\section{$3 \cdot 2$ 習熟度による脳賦活反応傾向の変化}

本実験では安静課題，観察課題及び再現課題を行った．安静課題は他の課題と比較する目的で設定した．しか し本論文においては計測域全体の脳賦活反応に着目するため, 局所的な計測チャンネルにおける各課題の脳賦活 反応傾向の比較を行わない. したがって，安静課題は解析対象から除外寸ることとした．また脳賦活反応には個 人差があり, より厳密な傾向を分析するためには, 被験者を増や寸こと, また実験データの蓄積が必要であると 考えられる.

認知心理学者である Alan Baddeley は, 短期記憶の一種としてワーキングメモリーを提唱した. Baddeley が提案 したワーキングメモリーのモデルでは，言語を推測，理解するためにリハーサルを伴って音韻情報を一時的に保 持する音韻ループと，視空間的情報を操作や保持を行う視空間的スケッチパッド，そしてこれら二つを統合した り調整したりするエピソードバッファーの三つの要素が存在し, これらのサブシステムをメインの中央実行系と いうシステムが調整している (Baddeley, 2000). 長期記憶は, 短期記憶から選択的に変換されることが知られて おり，見ま衩学習によって作業習熟するに伴い，ワーキングメモリーにおける視空間的スケッチパッドの活動は 低下し，長期記憶の想起機能の役割が増加すると考えられる．また，ワーキングメモリーの視空間的サブシステ ムは，対象の物体情報と空間的情報という二つの要素から成るという見解があり，サルを用いた実験では，物体 情報に関する神経は腹外側前頭前野に多く, 空間的情報に関する神経は背外側前頭前皮質に多い（Rainer et al., 1998; Kandel 他, 2014)。したがって組立作業の見まね学習を行う本実験においては，外側前頭前野の賦活傾向が 重要であると考えられる.

Table 2 Results of the imitation tasks.

\begin{tabular}{|c|c|c|c|c|c|c|c|c|c|c|c|c|c|c|}
\hline Subjects & Condition & \multicolumn{12}{|c|}{ Performed procedure ( The numbers indicate procedure index ) } & \multirow{2}{*}{$\begin{array}{c}\text { Total } \\
1 \\
\end{array}$} \\
\hline \multirow{2}{*}{ A } & First day & 1 & 4 & 2 & - & - & - & - & - & - & - & - & - & \\
\hline & Second day & 1 & 2 & 3 & 4 & 5 & 6 & 7 & 9 & 10 & 11 & 12 & - & 10 \\
\hline \multirow{2}{*}{ B } & First day & 2 & 1 & - & - & - & - & - & - & - & - & - & - & 0 \\
\hline & Second day & 1 & 2 & 3 & 4 & 5 & 6 & 7 & 9 & 10 & 11 & 12 & - & 10 \\
\hline \multirow{2}{*}{$\mathrm{C}$} & First day & 1 & 4 & 2 & - & - & - & - & - & - & - & - & - & 1 \\
\hline & Second day & 1 & 2 & 3 & 4 & 6 & 7 & 8 & 9 & 10 & 11 & 5 & 12 & 10 \\
\hline \multirow{2}{*}{$\mathrm{D}$} & First day & 1 & 2 & 4 & - & - & - & - & - & - & - & - & - & 2 \\
\hline & Second day & 1 & 2 & 3 & 4 & 5 & 6 & 7 & 8 & 9 & 10 & 11 & - & 10 \\
\hline \multirow{2}{*}{$\mathrm{E}$} & First day & 2 & - & - & - & - & - & - & - & - & - & - & - & 0 \\
\hline & Second day & 1 & 2 & 3 & 4 & 5 & 6 & 7 & 8 & 10 & 9 & 11 & 12 & 10 \\
\hline
\end{tabular}


図 4 に各実験の観察課題及び再現課題における Oxy-Hb のグループ解析による t-map 走す．また図 5 に各実 験の観察課題及び再現課題における Deoxy-Hb のグループ解析による t-map を, 図 6 に総へモグロビン (Total-Hb) のグループ解析による t-map を示す. Total-Hb は Oxy-Hb と Deoxy-Hb の総量である. コントラストはt 統計量を 示しており，白色に近づくほど賦活していることを示す．図 5 の t-map について，観察課題においては習熟前は 背外側前頭前野に広い範囲で Deoxy-Hb の上昇が見られるが，習熟後は上昇傾向が見られない. 図 6 の t-map に ついては, 総へモグロビン変化を血液量の変動として仮定して考えると, 観察課題と再現課題における習熟前後 の結果の内, 習熟前の観察課題で最も血液量の増加が広範囲に見られることが分かる. なお，先行研究では， Oxy-Hb が局所脳血流と関連し, 脳の賦活を最も反映するとされている (Hoshi et al., 2001). また Oxy-Hb は MRI の BOLD 信号と相関性があることが示されており (Okamoto et al., 2004), 本論文ではこの観点から, 以下に Oxy-Hb について考察を行う．解剖学的位置と計測チャンネルの対応付けは，NIRS-SPMにより推定を行った.

作業習熟前の観察課題においては，背外側前頭前野に賦活傾向が見られ，前頭極を含む前頭前野の広範囲にお いて賦活は見られない. 背外側前頭前野が賦活するという結果は先行研究と一致し, 被験者が視空間的情報の操 作及び保持を行っていたことが示唆される，作業習熟後においては，習熟前と比較して，前頭極の一部である Ch.10 近傍を除いて，計測チャンネル全体で賦活傾向を示している．被験者は，表 1 の通り実験前にも同様の課 題を行っており, 表 2 の通り習熟後は高い精度で作業を再現していた. 実験後のアンケートにおいて, 手順を正 確に記憶できたかという問いに対して， 1 が悪い評価で 5 が良い評価という 5 段階で評価したところ, 被験者 4 人は 5 , 被験者 1 人は 4 の評価であった。このことから被験者は作業習熟に自覚的であり，見ま数学習時は映像 に対して習熟前に比べて注視していなかったと推測できる.したがって，広範囲な賦活傾向はデフォルトモード ネットワークによる影響である可能性が考えられる. デフォルトモードネットワークは, 個人が外部環境に集中 していない時に優先的に活動が高まる脳のネットワークであり, 自己の記憶検索や未来の想像, 他者の視点を考 えるといった，内的に焦点を当てた課題を行っているときに活性化する．中心となる領域は，内側前頭前野，前 部帯状皮質，膨大後部皮質，下頭頂葉，外側側頭葉など広範囲に及ぶ（Buckner et al., 2008）。したがって，習熟 後の観察課題における前頭極の広範囲な脳賦活傾向は, 被験者が既に内容を把握しており観察に集中しなくなっ たこと, また被験者がこれまでの学習で得た情報の確認や, 再現課題を想像するなど, 自身の内的な思考を行っ たことによる影響であると考えられる.

再現課題の作業習熟前では, 左背外側前頭前野の一部である Ch.5 近傍に局所的な賦活傾向が見られる. この賦 活傾向も先行研究と同様に，ワーキングメモリーによる記憶の保持に関わる賦活と考えられる. また習熟前の再 現課題において実際に作業を正確に再現することのできた被験者はおらず，被験者は実際の作業を行うために組 立部品に注意を向けているが，保持した記憶による動作の再現には対応できていないという状況が想定される. デフォルトモードネットワークの影響よりも，外部環境へ集中していることにより，局所的な賦活であった可能 性が考えられる．これに対して，作業習熟後では背外側前頭前野において賦活傾向が見られ，前頭極および下前 頭回の一部においても局所的な賦活傾向が見られた．既に作業手順を理解している被験者は，ワーキングメモリ 一により，視空間的情報の保持と操作，そしてこれまでの作業の記憶をエピソードバッファーにより想起すると いった状況が推察される．また実際に被験者が作業を行うため，作業のために視空間的情報の保持及び操作も必 要となる．再現課題では，作業に習熟するほどワーキングメモリーの機能が必要となり，背外側前頭前野におい て賦活傾向を示したと考えられる.

ワーキングメモリーでより深く情報処理をした方が，前頭前野外側部や側頭葉内側部において強い賦活が見ら れ, 長期記憶の成績が良いという先行研究の結果が報告されている（甘利, 田中, 2008; Blumenfeld and Ranganath, 2007)。また，見まね学習ではワーキングメモリーの視空間的スケッチパッドが重要であり，本実験においても背 外側前頭前野が賦活傾向を示した．作業習熟後の観察課題においては，背外側前頭前野を含めた，広範囲な賦活 傾向が見られた．脳賦活傾向と作業習熟を考察する上では，賦活の範囲だけではなく，賦活強度についても考慮 する必要があると考えられる。 


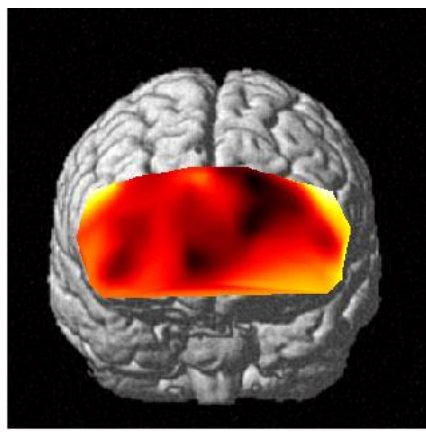

(a)

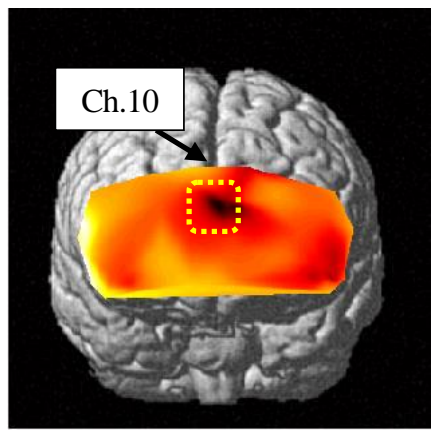

(c)

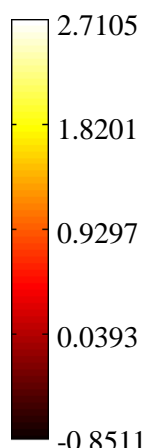

$-0.8511$

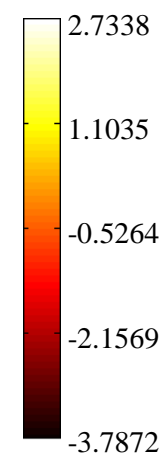

$-3.7872$
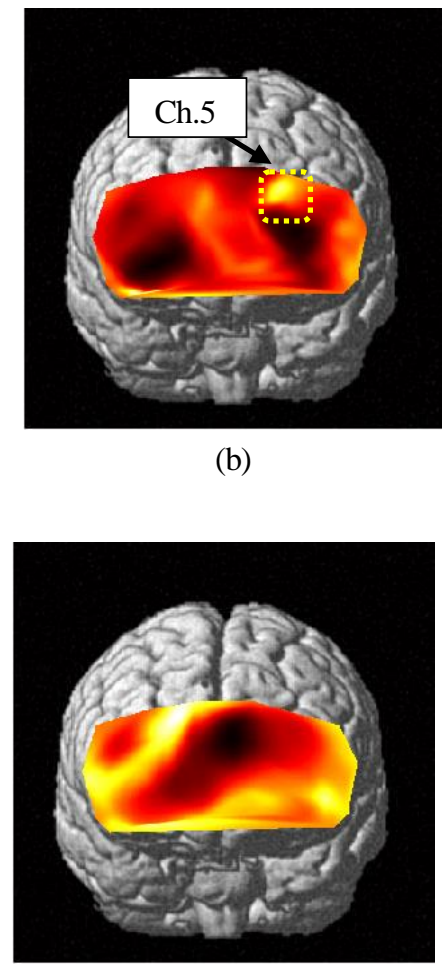

(d) (b)
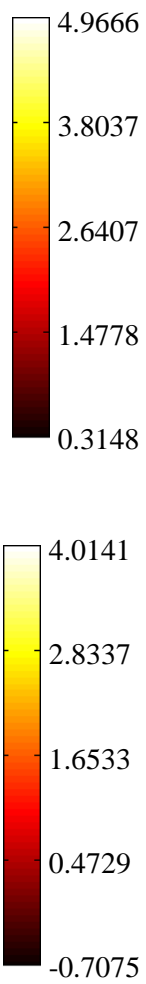

0.7075

Fig. 4 Group t-statistic maps of Oxy-Hb from observation task and imitation task. (a) Activation map from pre-learning observation task, (b) pre-learning imitation task, (c) post-learning observation task and (d) post-learning imitation task. The surrounding area of the channels are shown by dashed lines.

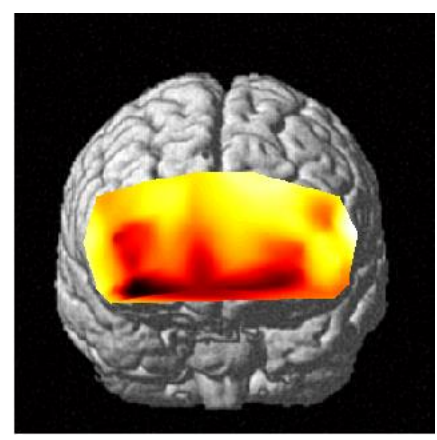

(a)

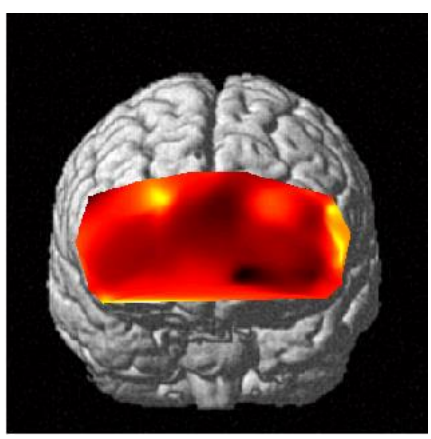

(c)

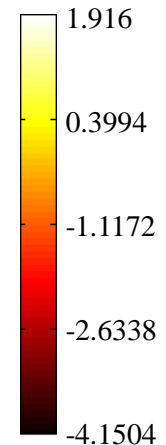

$-4.1504$

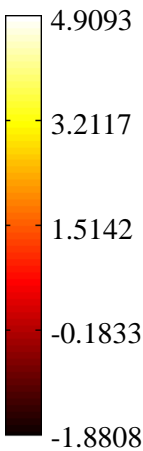

$-1.8808$
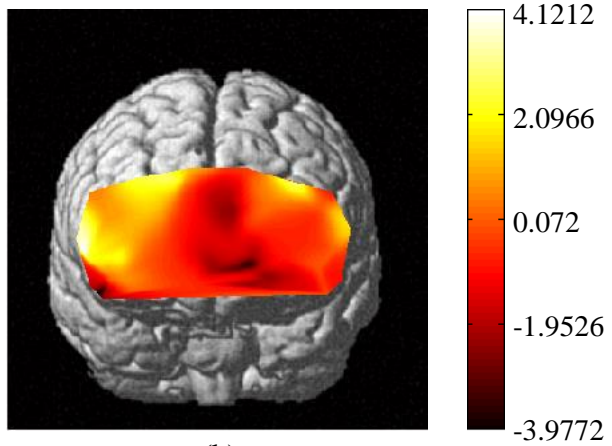

(b)

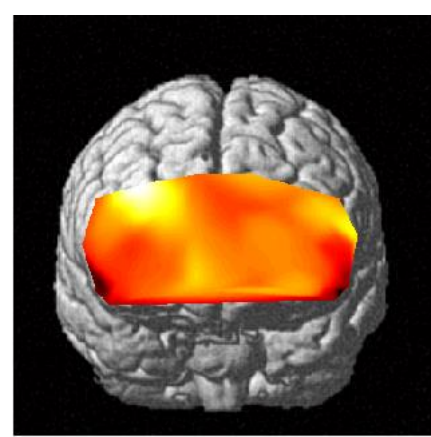

(d)

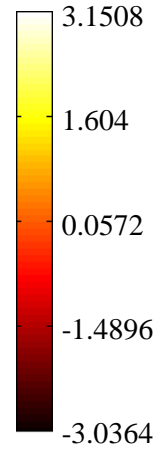

.0364
Fig. 5 Group t-statistic maps of Deoxy-Hb from observation task and imitation task. (a) Activation map from pre-learning observation task, (b) pre-learning imitation task, (c) post-learning observation task and (d) post-learning imitation task. 


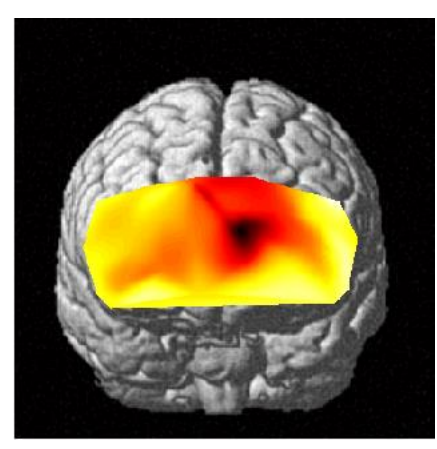

(a)

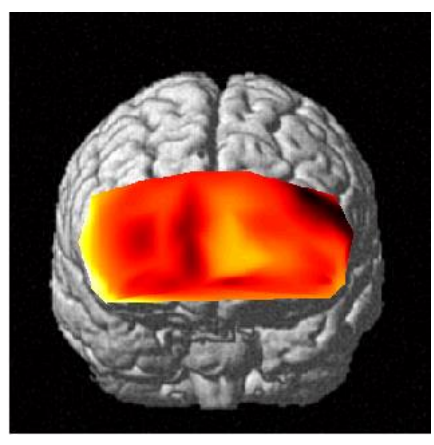

(c)

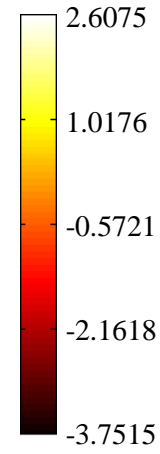

$-3.7515$

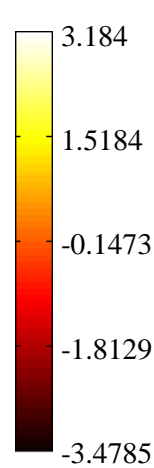

$-3.4785$

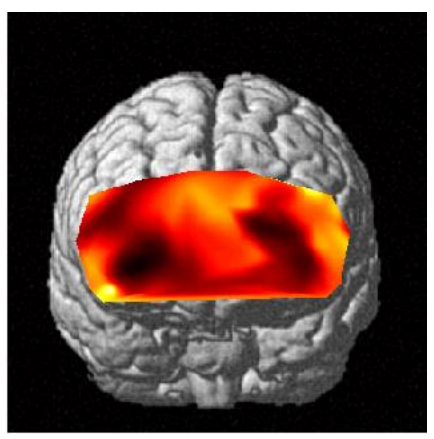

(b)

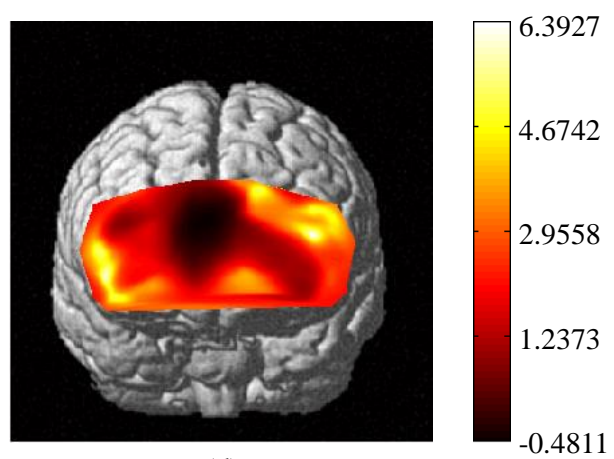

(d)

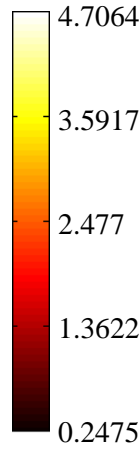

.2475

6.3927

6742

.9558

1.2373

0.4811
Fig. 6 Group t-statistic maps of Total-Hb from observation task and imitation task. (a) Activation map from pre-learning observation task, (b) pre-learning imitation task, (c) post-learning observation task and (d) post-learning imitation task.

\section{4. 結 言}

本論文では，これまでの局所的な脳賦活反応傾向の考察に加えて，計測部位全体の脳賦活反応傾向について， 作業習熟との関連性を考察した．見まね学習ではワーキングメモリーの視空間的スケッチパッドが重要であり， 本実験において背外側前頭前野が賦活傾向を示した。 また作業習熟後の観察課題における広範囲な賦活傾向は, デフォルトモードネットワークの影響と考えられる．脳賦活反応に基づいて見まね学習の習熟程度を評価寸るた めには, 背外側前頭前野の賦活傾向が重要であり, デフォルトモードネットワークの影響を考慮する必要がある ことが示唆された. 再現課題においては, 習熟した後においても, 局所的な脳賦活傾向を示すことが示唆された. 今後は情報処理手法として見まね学習の脳機能システムを理解するために, 脳賦活傾向を分析するだけでなく, 賦活部位間のネットワークを推定するといったアプローチにも取り組みたい.

\section{謝 辞}

論文の執筆にあたり，埼玉大学大学院理工学研究科人間支援・生産科学部門の水野毅教授にご指導を頂きまし た. 貴重なご助言を頂き，深く感謝申し上げます.

本論文における実験は, 埼玉大学大学院理工学研究科戦略的研究部門の綿貫啓一教授の統括寸るヒューマンイ ンターフェイス研究室において実施したものであり, 記して感謝致します. また, 実験に協力して頂いた同研究 室学生諸氏にも，感謝申し上げます。 


\section{文献}

相原啓人, 清水涼, 高仲隆太郎, 綱島均, ウェアラブル NIRS を用いた鉄道運転中の脳活動計測と評価，日本機械 学会論文集, Vol. 85, No. 871 (2019), DOI: 10.1299/transjsme.18-00116.

甘利俊一, 田中啓治, 認識と行動の脳科学 (2008), pp.135-136, 137-138, 東京大学出版会.

淺賀裕介, 綿貫啓一, 身体知獲得過程における動作の再現性と脳賦活反応との関係，日本機械学会論文集, Vol. 82, No. 842 (2016), DOI: 10.1299/transjsme.16-00150.

Baddeley, A., The episodic buffer: A new component of working memory?, Trends in Cognitive Sciences, Vol. 4, No. 11 (2000), pp.417-423.

Blumenfeld, R., S. and Ranganath, C., Prefrontal cortex and long-term memory encoding: an integrative review of findings from neuropsychology and neuroimaging, Neuroscientist, Vol. 13 (2007), pp.280-291.

Buckner, R., L., Andrews-Hanna, J., R. and Schacter, D., L., The brain's default network: anatomy, function, and relevance to disease, Annals of the New York Academy of Sciences, Vol. 1124 (2008), pp.1-38.

di Pellegrino, G., Fadiga, L., Fogassi, L., Gallese, V. and Rizzolatti, G., Understanding motor events: a neurophysiological study, Experimental Brain Research, Vol. 91, No. 1 (1992), pp.176-180.

江田英雄, NIRS の問題点と今後の展開, システム制御情報学会誌システム/ 制御/ 情報, Vol. 53, No. 4 (2009), pp.155-161.

Fadiga, L., Fogassi, L., Pavesi, G. and Rizzolatti, G., Motor facilitation during action observation: a magnetic stimulation study, Journal of Neurophysiology, Vol. 73, No. 6 (1995), pp.2680-2683.

富士経済, パワーアシストスーツ、ドローン・無人ヘリなどの需要が急増: 業務・サービスロボット関連の世界 市場を調查(online), available from < https://www.fuji-keizai.co.jp/market/detail.html?cid=18036\&view_type=2>, (参 照日 2020 年 10 月 11 日).

Hatakenaka, M., Miyai, I., Mihara, M., Sakoda, S. and Kubota, K., Frontal regions involved in learning of motor skill --a functional NIRS study, NeuroImage Vol. 34 (2007), pp.109-116.

Hoshi, Y., Kobayashi, N. and Tamura, M., Interpretation of near-infrared spectroscopy signals: a study with a newly developed perfused rat brain model, Journal of Applied Physiology, Vol. 90 (2001), pp.1657-1662.

今井雅子, 高橋礼恵, 戸田智美, 三沢岳志, 源栄克則, 先端技術トピックにおける技術動向予測 一家庭用ロボッ トの将来像を俯瞰した投資技術選定一，情報の科学と技術, Vol. 70, No. 1 (2020), pp.34-40.

稲邑哲也, 中村仁彦, ミメシス理論に基づく見ま祗学習とシンボル発達の統合モデル, 日本神経回路学会誌, Vol. 12, No. 1 (2005), pp.74-80.

Jang, K. E., Tak, S., Jung, J., Jang, J., Jeong, Y. and Ye, J. C., Wavelet-MDL detrending for near-infrared spectroscopy (NIRS), Journal of Biomedical Optics, Vol. 14, No. 3 (2009), pp.1-13.

内閣府, 内閣府の政策: 科学技術政策: Society5.0 (online), available from <https://www8.cao.go.jp/cstp/society5_0/>, (参照日 2020 年 10 月 11 日).

Kandel, E. R., Schwartz, J. H., Jessell, T. M., Siegelbaum, S. A. and Judspeth, A. J. 編, 金澤一郎, 宮下保司 日本語版監 修, カンデル神経科学 (2014), pp.1411-1412,メディカル・サイエンス・インターナショナル.

Li, H., Tak, S. and Ye, J.C., Lipschitz-Killing curvature based expected Euler characteristics for p-value correction in fNIRS, Journal of Neuroscience Methods, Vol. 204 (2012), pp.61-67.

Marr, D., 乾敏郎, 安藤広志訳, ビジョン-視覚の計算理論と脳内表現- (1987), pp.26-29, 産業図書.

Meltzoff, A., N., Infant imitation and memory: nine-month-olds in immediate and deferred tests, Child development, Vol. 59, No. 1 (1988), pp.217-225.

野澤孝之, 近藤敏之, NIRS 脳計測データのオンライン分析のためのアーティファクト除去手法の比較, 第 24 回生 体・整理工学シンポジウム論文集 (2009).

Ohuchida, K., Kenmotsu, H., Yamamoto, A., Sawada, K., Hayami, T., Morooka, K., Takasugi, S., Konishi, K., Ieiri, S., Tanoue, K., Iwamoto, Y., Tanaka, M. and Hashizume, M., The frontal cortex is activated during learning of endoscopic procedures, Surgical Endoscopy, Vol. 23 (2009), pp.2296-2301.

Okamoto, M., Dan, H., Shimizu, K., Takeo, K., Amita, T., Oda, I., Konishi, I., Sakamoto, K., Isobe, S., Suzuki, T., Kohyama, K. and Dan, O., Multimodal assessment of cortical activation during apple peeling by NIRS and fMRI, NeuroImage, Vol. 21 (2004), pp.1275-1288.

尾崎文夫，高齢者生活支援ロボットの現状，日本老年医学会雑誌，Vol. 57, No. 3 (2020), pp.224-235.

Rainer, G., Asaad, W., F. and Miller, E., K., Memory fields of neurons in the primate prefrontal cortex, Proceedings of the National Academy of Sciences of the United States of America, Vol. 95 (1998), pp.15008-15013. 
鮫島和行, 銅谷賢治, 川人光男, 強化学習 MOSAIC: 予測性によるシンボル化と見まね学習, 日本ロボット学会 誌, Vol. 19, No. 5 (2001), pp.551-556.

清水俊之, 久保田直行, 見ま裈習における SSGA と MNNを用いた軌道学習, 日本機械学会ロボティクス・メカ トロニクス講演会講演論文集 (2006).

田㴊一真, 谷口忠大, 椹木哲夫, 模倣学習と強化学習の調和による効率的行動獲得, 第 20 回人工知能学会年次大 会論文集 (2006).

Tak, S., Jang, J., Lee, K. and Ye, J. C., Quantification of CMRO2 without hypercapnia using simultaneous near-infrared spectroscopy and fMRI measurements, Physics in Medicine \& Biology, Vol. 55, No. 11 (2010), pp.3249-3269.

Tak, S., Yoon, S. J., Jang, J. Yoo, K., Jeong, Y. and Ye, J. C., Quantitative analysis of hemodynamic and metabolic changes in subcortical vascular dementia using simultaneous near-infrared spectroscopy and fMRI measurements, NeuroImage, Vol. 55 (2011), pp.176-184.

鳥山悟, 佐達秀敏, 中村純二, 近赤外分光法を用いた顔肌への自己接触時の脳活動計測, 日本感性工学会論文誌 (2020), pp.255-261.

Wagner, A., D., Schacter, D., L., Rotte, M., Koutstaal, W., Maril, A., Dale, A., M., Rosen, B., R.; and Buckner, R., L., Building memories: remembering and forgetting of verbal experiences as predicted by brain activity, Science, Vol. 282 (1998), pp.1188-1191.

Ye, J.C., Tak, S., Jang, K.E., Jung, J.W. and Jang, J.D., NIRS-SPM: statistical parametric mapping for near-infrared spectroscopy, NeuroImage, Vol. 44 (2009), pp.428-447.

\section{References}

Aibara, K., Shimizu, R., Takanaka, R. and Tsunashima, H., Measurement and evaluation of brain activity for train drivers using wearable NIRS, Transactions of the JSME (in Japanese), Vol. 85, No. 871 (2019), DOI: 10.1299/transjsme.18-00116.

Amari, S. and Tanaka, K., Brain science of cognizance and behavior (2008), pp.135-136, 137-138, University of Tokyo Press (in Japanese).

Asaka, Y. and Watanuki, K., The relationship between brain activity and accuracy of replicating actions in the process of embodied knowledge acquisition, Transactions of the JSME (in Japanese), Vol. 82, No. 842 (2016), DOI: 10.1299/transjsme.16-00150.

Baddeley, A., The episodic buffer: A new component of working memory?, Trends in Cognitive Sciences, Vol. 4, No. 11 (2000), pp.417-423.

Blumenfeld, R., S. and Ranganath, C., Prefrontal cortex and long-term memory encoding: an integrative review of findings from neuropsychology and neuroimaging, Neuroscientist, Vol. 13 (2007), pp.280-291.

Buckner, R., L., Andrews-Hanna, J., R. and Schacter, D., L., The brain's default network: anatomy, function, and relevance to disease, Annals of the New York Academy of Sciences, Vol. 1124 (2008), pp.1-38.

di Pellegrino, G., Fadiga, L., Fogassi, L., Gallese, V. and Rizzolatti, G., Understanding motor events: a neurophysiological study, Experimental Brain Research, Vol. 91, No. 1 (1992), pp.176-180.

Eda, H., Issues and future developments of NIRS, Journal of the Institute of Systems, Control and Information Engineers, Vol. 53, No. 4 (2009), pp.155-161 (in Japanese).

Fadiga, L., Fogassi, L., Pavesi G. and Rizzolatti, G., Motor facilitation during action observation: a magnetic stimulation study, Journal of Neurophysiology, Vol. 73, No. 6 (1995), pp.2680-2683.

Fuji Keizai Group, Surging demand for power-assisted exoskeleton, drone: unmanned aerial vehicle and others, global market survey on work/ service robot (online), available from < https://www.fuji-keizai.co.jp/market/detail.html?cid=18036\&view_type=2>, (accessed on 11 October, 2020) (in Japanese).

Hatakenaka, M., Miyai, I., Mihara, M., Sakoda, S. and Kubota, K., Frontal regions involved in learning of motor skill --a functional NIRS study, NeuroImage Vol. 34 (2007), pp.109-116.

Hoshi, Y., Kobayashi, N. and Tamura, M., Interpretation of near-infrared spectroscopy signals: a study with a newly developed perfused rat brain model, Journal of Applied Physiology, Vol. 90 (2001), pp.1657-1662.

Imai, M., Takahashi, H., Toda, S., Misawa, T. and Tomosaka, K., Technology trends and technology predictions in latest technical topics - selecting technologies to invest in, overviewing the future of home robots -, Journal of Information 
Science and Technology Association, Vol. 70, No. 1 (2020), pp.34-40 (in Japanese).

Inamura, T. and Nakamura, Y., An integrated model of imitation learning and symbol development based on mimesis theory, Journal of Japanese Neural Network Society, Vol. 12, No. 1 (2005), pp.74-80 (in Japanese).

Jang, K. E., Tak, S., Jung, J., Jang, J., Jeong, Y. and Ye, J. C., Wavelet-MDL detrending for near-infrared spectroscopy (NIRS), Journal of Biomedical Optics, Vol. 14, No. 3 (2009), pp.1-13.

Japan, Cabinet Office, Policy of the cabinet office: Science and technology policy: Society5.0 (online), available from <https://www8.cao.go.jp/cstp/society5_0/>, (accessed on 11 October, 2020) (in Japanese).

Kandel, E. R., Schwartz J. H., Jessell, T. M., Siegelbaum, S. A. and Judspeth, A. J. ed., Supervised in Japanese edition by Kanazawa, I. and Miyashita, Y., Principles of neural science (2014), pp.1411-1412, Medical Sciences International (in Japanese).

Li, H., Tak, S. and Ye, J.C., Lipschitz-Killing curvature based expected Euler characteristics for p-value correction in fNIRS, Journal of Neuroscience Methods, Vol. 204 (2012), pp.61-67.

Marr, D., Translated by Inui, T. and Ando, H., VISION: a computational investigation into the human representation and processing of visual information (1987), pp.26-29, Sangyo Tosyo (in Japanese).

Meltzoff, A., N., Infant imitation and memory: nine-month-olds in immediate and deferred tests, Child development, Vol. 59, No. 1 (1988), pp.217-225.

Nozawa, T. and Kondo, T., Comparison of artifact reduction methods for real-time analysis of fNIRS data, Proceedings of the 24th Biological and Physiological Engineering Symposium (2009) (in Japanese).

Ohuchida, K., Kenmotsu, H., Yamamoto, A., Sawada, K., Hayami, T., Morooka, K., Takasugi, S., Konishi, K., Ieiri, S., Tanoue, K., Iwamoto, Y., Tanaka, M. and Hashizume, M., The frontal cortex is activated during learning of endoscopic procedures, Surgical Endoscopy, Vol. 23 (2009), pp.2296-2301.

Okamoto, M., Dan, H., Shimizu, K., Takeo, K., Amita, T., Oda, I., Konishi, I., Sakamoto, K., Isobe, S., Suzuki, T., Kohyama, K. and Dan, O., Multimodal assessment of cortical activation during apple peeling by NIRS and fMRI, NeuroImage, Vol. 21 (2004), pp.1275-1288.

Ozaki, F., The current status of elderly care robots, Journal of the Japan Geriatrics Society, Vol. 57, No. 3 (2020), pp.224-235 (in Japanese).

Rainer, G., Asaad, W., F. and Miller, E., K., Memory fields of neurons in the primate prefrontal cortex, Proceedings of the National Academy of Sciences of the United States of America, Vol. 95 (1998), pp.15008-15013.

Samejima, K., Doya, K. and Kawato, M., MOSAIC reinforcement learning architecture: symbolization by predictability and mimic learning by symbol, Journal of the Robotics Society of Japan, Vol. 19, No. 5 (2001), pp.551-556 (in Japanese).

Shimizu, T. and Kubota, N., Behavior learning for imitation learning based on SSGA and MNN, Proceedings of the JSME conference on Robotics and Mechatronics (2006) (in Japanese).

Tabuchi, K., Taniguchi, T. and Sawaragi, T., Efficient acquisition of behaviors by harmonizing reinforcement learning with imitation learning, Proceedings of the 20th Annual Conference of the Japanese Society for Artificial Intelligence (2006) (in Japanese).

Tak, S., Jang, J., Lee, K. and Ye, J. C., Quantification of CMRO2 without hypercapnia using simultaneous near-infrared spectroscopy and fMRI measurements, Physics in Medicine \& Biology, Vol. 55, No. 11 (2010), pp.3249-3269.

Tak, S., Yoon, S. J., Jang, J. Yoo, K., Jeong, Y. and Ye, J. C., Quantitative analysis of hemodynamic and metabolic changes in subcortical vascular dementia using simultaneous near-infrared spectroscopy and fMRI measurements, NeuroImage, Vol. 55 (2011), pp.176-184.

Toriyama, S., Sadachi, H. and Nakamura, J., Measurement of brain activity during facial self-touching by near-infrared spectroscopy, Transactions of Japan Society of Kansei Engineering (2020), pp.255-261 (in Japanese).

Wagner, A., D., Schacter, D., L., Rotte, M., Koutstaal, W., Maril, A., Dale, A., M., Rosen, B., R. and Buckner, R., L., Building memories: remembering and forgetting of verbal experiences as predicted by brain activity, Science, Vol. 282 (1998), pp.1188-1191.

Ye, J.C., Tak, S., Jang, K.E., Jung, J.W. and Jang, J.D., NIRS-SPM: statistical parametric mapping for near-infrared spectroscopy, NeuroImage, Vol. 44 (2009), pp.428-447. 